\section{Dilatomery of stove tile ceramic material Letovice}

GABRIEL VARGA - Dpt. of Physics, Constantine the Philosopher University - gvarga@ukf.sk IGOR ŠTUBŇA - Dpt. of Physics, Constantine the Philosopher University - istubna@ukf.sk

\section{Letovice-i kályhacsempe kerámia anyagának dilatometriája}

A kaolin és a kvarc fontos szerepet töltenek be a kályhacsempe anyagában, és szembetúnóen befolyásolják a dilatogrammot. $900-1100^{\circ} \mathrm{C}$ közötti hômérsékleten megy végbe a spinell és a mullit kialakulása, és megjelenik az üveges fázis is. A minták ismételt égetései nem befolyásolják a dilatometrikus viselkedést, ez arról tanúskodik, hogy a kerámia anyag már az elsô égetés után stabilizálódik. A $20-530^{\circ} \mathrm{C}$ közötti hômérséklet tartományban az égetett kerámiák lineáris hôtágulási együtthatójának értéke 6,2 × 10-6 $\mathrm{K}^{-1}$.

\section{Introduction}

The reliance on the tile stoves in houses appears outmoded if compared to gas or electrical heating. The related energetic problems mandate using some alternative and cheap energy carriers such as wood. Ceramic tile stoves of the classical type not only offer a problem solving option but also are stylish and decorative in the houses.

Ceramic material for such stove tiles is typically made from commercial materials that are mixed by a formula, which was developed through empirical experience during the years of testing until the required quality was reached. A literature search reveals that the ceramic material for tiles was not apparently studied extensively. Furthermore, many of the physical properties remain unknown.

It is assumed that the expected properties of the stove tile material are chemical and heat resistance. As a stove tile undergoes testing to high temperature gradients, on the inner side the temperature may reach $900{ }^{\circ} \mathrm{C}$, while the temperature is only $80-90{ }^{\circ} \mathrm{C}$ on the outer side. To stand such temperature difference without damage, the tile must have low thermal expansion.

So it is reasonable to perform thermodilatometric study of the stove tile material to gain more knowledge about processes, which take place during firing. It may be assumed that thermodilatometry is one of the most important methods which can be applied for investigation of sintering of ceramic materials. Axiomatically sintering is accompanied with shrinkage of the sample, and can be successfully measured with a dilatometer [1].

The objective of this article is to provide a dilatometric study of the ceramic material which is used for making fireproof ceramic tiles at the ceramic plant Keramika Letovice (Czech Republic).

\section{Samples and method of measurement}

Material for the samples was combined from some commercial raw materials, most of which contain significant part of kaolin. The resulting chemical composition of the dried form is showed in Tab. 1.
RNDr. Gabriel Varga

(19.10.1979., Slovakia. Nationality: hungarian) Education: 2005: Constantine the Philosopher

University in Nitra, chemistry - computer science (degree - Mgr.). 2005, 2007: Slovak Technical University - Summer School of Thermal Analysis - certificate. 2006: Constantine the Philosopher University in Nitra - graduated as doctor of natural sciences (RNDr.). 2005: Constantine the Philosopher University in Nitra - PhD. student. Field of research: Physics of condensed matter and acoustic - Heatproof ceramic materials.

Doc. Ing Igor Štubňa, CSc. (19. 5. 1941., Slovakia) Education: 1965: Dipl. Ing. degree from the Electrophysical faculty of Sankt Petersburg Electrotechnical University physics of solid state. 1980: PhD (CSc.) degree from the Institute of Physics of Slovak Academy of Sciences (PhD thesis on mechanical properties of electroporcelain). Field of research: Mechanical and thermophysical properties of the kaoline-base ceramics, firing of ceramics, measurement of the dynamical mechanical properties (sound, moduli of elasticity).

\begin{tabular}{ccccccccc}
$\mathbf{A l}_{2} \mathbf{O}_{3}$ & $\mathbf{F e}_{2} \mathbf{O}_{3}$ & $\mathrm{TiO}_{2}$ & $\mathbf{S i O}_{2}$ & $\mathbf{C a O}$ & $\mathbf{M g O}$ & $\mathbf{N a}_{2} \mathbf{O}$ & $\mathbf{K}_{2} \mathbf{O}$ & L.0.I. \\
23,08 & 1,47 & 0,68 & 62,4 & 1,5 & 0,4 & 0,72 & 2,45 & 7,3 \\
\hline
\end{tabular}

Table 1. Chemical composition of the green ceramic mixture (mass \%)

1. táblázat A kerámia nyersanyag kémiai összetétele (tömeg \%)

The samples were prepared from the water suspension by casting to the gyps form. After drying the samples have the dimension $4 \times 4 \times 35 \mathrm{~mm}$. The dilatometric analysis was performed with the push-rod dilatometer [2]. The maximum temperature $1100{ }^{\circ} \mathrm{C}$ was reached by a heating rate $5^{\circ} \mathrm{C} / \mathrm{min}$.

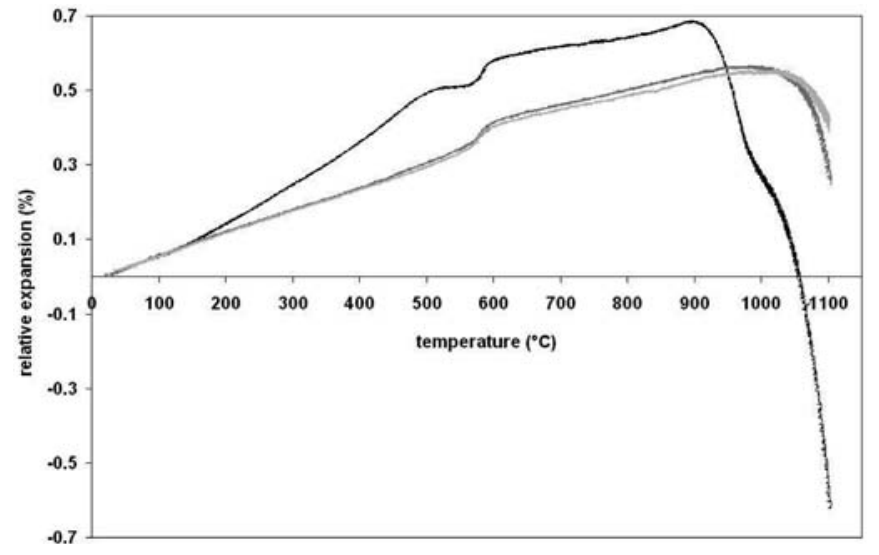

Fig. 1. Dilatometric curves of the 1st heating (black) and 2nd and 3rd heating (gray) 1. ábra Az elsö égetés (fekete), illetve a második és harmadik égetés (szürke) dilatogrammjai

\section{Results and discussion}

During the heating, the green sample changed its structure and composition. Thus these changes determined the dilatometric behavior. The results of dilatometric analysis are shown in Fig. 1.

It is known that the physically bounded water escapes from the pores and surfaces of the crystals in the temperature region $20-150{ }^{\circ} \mathrm{C}[3,4]$. This process did not manifest itself in Fig. 1, 
even though the sample contains about 1 mass $\%$ of the free water. Dehydroxylation begins after reaching $450{ }^{\circ} \mathrm{C}$. In pure kaolin, dehydroxylation was accompanied with shrinkage of the sample $[4,5]$. However in this case, only a short plateau is apparent; then after a steep course of the curve appears. This is caused by the $\alpha \rightarrow \beta$ transition of the quartz at $573^{\circ} \mathrm{C}$. It may be expected that a contraction of the sample takes place after this transition. This is attributed to the fact that the sample contains primarily kaolin. The curve of the first heating however, did not reflect that result. Thus it is assumed that the sample contains significant amount of other minerals, which do not undergo to dehydroxylation and thermal expansion continues over ranges of the heating. At the temperatures $900-950{ }^{\circ} \mathrm{C}$, steep contraction appears apparently caused by the transition of the metakaolinite into spinell and primary mullite $[6,7]$. It may be assumed that glassy phase is created at the highest temperatures. That was verified by the second and the third heating curves.

It was discovered that the sample contains significant part of glassy phase and unsolved quartz grains. A presence of the glassy phase causes the softening of the material at temperatures above $1000{ }^{\circ} \mathrm{C}$ as recorded by the push-rod dilatometer.

The ceramic tiles are fired two times in the ceramic plant, therefore the test firing was repeated to simulate the industrial praxis. The end result after the second heating does not change the dilatometric properties as evidenced by the two lower dilatometric curves in Fig. 1. The dilatometric line of the fired ceramics is linear in the most important temperature region from an exploitation point of view. A coefficient of the linear thermal expansion is $6.2 \times 10^{-6} \mathrm{~K}^{-1}$ for the fired ceramics in the region of $20-530^{\circ} \mathrm{C}$.

To be able to specify description of dilatomentric behavior of the investigated material in greater details, additional analysis, mainly XRD, is necessary.

\section{Conclusion}

In the ceramic plant, Keramika Letovice, kaolin plays significant role, in the materials used and markedly affects the dilatometric curve. At temperatures $900-1100{ }^{\circ} \mathrm{C}$ creation of the spinell, mullite, and glassy phase occurs. Repeated firings of the samples do not affect dilatometric behavior, which indicates that the ceramic material is stable after the first firing.

\section{Acknowledgement}

This work was supported by the grant VEGA 1/3179/06. The authors want to thank the administration at the ceramic plant Keramika Letovice for the samples made available and for general support for the research.

\section{References}

[1] Paganelli, M.: Using the optical dilatometer to determine sintering behavior. Am. Cer. Soc. Bull, 81, 2002, 25-30

[2] Štubňa, I. - Važanová, A. - Varga, G. - Hrubý, D.: Simple push-rod dilatometer for dilatometry of ceramics. In: Proc. Conf. Research and teaching of physics in the context of university education, SPU Nitra, Nitra 2007, 69-74

[3] Hanykýř, V. - Kutzendrfer, J.: Technologie keramiky. Silis Praha a Vega Hradec Králové, 2000

[4] Č́ćčel, B. - Novák I. - Horváth, I.: Mineralogy and crystallochemistry of clays. SAV, Bratislava 1981

[5] Brindley, G. W. - Sharp, J. H. - Patterson, J. H. - Narahari, B.N.: Kinetics and mechanism of dehydroxylation process, I. temperature and vapor pressure dependence on dehydroxylation of kaolinite. The Amer. Mineralogist, 52, 1967, 201-211

[6] Brindley, G. W. - Nakahira, M.: The kaolinite-mullite reaction series: I, A survay of outstanding problems. J. Amer. Ceram. Soc., 42, 1959, 311-314

[7] Brindley, G. W. - Nakahira, M.: The kaolinite-mullite reaction series: II, Metakaolin. J. Amer. Ceram. Soc., 42, 1959, 314-318 